\title{
'Home' and 'away' litter decomposition depends on the size fractions of the soil biotic community
}

\author{
Yingbin Li ${ }^{\mathrm{a}, \mathrm{b}}$, G.F. (Ciska) Veen ${ }^{\mathrm{b}}$, W.H. Gera Hol ${ }^{\mathrm{b}}$, Simon Vandenbrande ${ }^{\mathrm{b}}$, S. Emilia Hannula ${ }^{\mathrm{b}}$, \\ Freddy C. ten Hooven ${ }^{\mathrm{b}}$, Qi Li ${ }^{\mathrm{a}, *}$, Wenju Liang ${ }^{\mathrm{a}}$, T. Martijn Bezemer ${ }^{\mathrm{b}, \mathrm{c}}$ \\ a Institute of Applied Ecology, Chinese Academy of Sciences, Shenyang, 110016, China \\ ${ }^{\mathrm{b}}$ Department of Terrestrial Ecology, Netherlands Institute of Ecology (NIOO-KNAW), Wageningen, 6700 AB, the Netherlands \\ ${ }^{\mathrm{c}}$ Institute of Biology, Section Plant Ecology and Phytochemistry, Leiden University, Leiden, 2300 RA, the Netherlands
}

\section{A R T I C L E I N F O}

\section{Keywords:}

Decomposition

Home-field advantage

Fractionation

Soil microbial community

Specialization

Plant-soil interactions

\begin{abstract}
A B S T R A C T
The 'home-field advantage' (HFA) hypothesis predicts that litter decomposition is accelerated in its home environment (i.e. in conspecific soil). Soil organisms play a key role in driving such HFA effects. Soil biota have a large range of body sizes, referred to as size fractions, which may influence their roles in the decomposition process and in the generation of HFA effects. However, how HFA effects depend on the different size fractions of the soil biotic community is unknown. We conducted a microcosm decomposition experiment to examine how size fractions of the soil biotic community affected litter decomposition and HFA effects. In a semi-natural grassland in the Netherlands, we collected leaf litter and soil from two abundant forbs: Tanacetum vulgare and Jacobaea vulgaris. Watery extracts of the soils were sieved through differently-meshed sieves (ranging from 850 $\mu \mathrm{m}$ to $6 \mu \mathrm{m}$ ) to obtain soil communities of different size fractions. Microcosms were inoculated with these different size fractions of the soil biotic community and we examined their effects on microbial composition, litter mass loss and HFA effects. Three months after inoculation, the diversity of the fungal community in the inoculated pots decreased with decreasing size fractions of the soil biotic community. Similarly, litter mass loss also decreased with decreasing soil biotic community size. In contrast, the HFA effect increased with decreasing size fractions of the soil biotic community, but these differences disappeared after six months of decomposition. Our results indicate that soil microorganisms, mainly the smallest size fractions, are specialized to decompose specific resources and thus promote HFA effects, but that their effect is only apparent during specific stages of litter decomposition.
\end{abstract}

\section{Introduction}

Litter decomposition is a fundamental ecosystem process that drives nutrient and carbon cycling worldwide (Cadisch and Giller, 1997; Bradford et al., 2017). It is increasingly acknowledged that litter decomposition accelerates in the habitat where the litter originates from compared to other habitats, and this has been referred to as the home-field advantage (HFA) effect (Hunt et al., 1988; Gholz et al., 2000; Ayres et al., 2009). There is increasing recognition that HFA is the result of specific decomposer communities that are specialized to break down the litter from the plant species they are associated with, compared to litter from other plant species (Austin et al., 2014; Palozzi and Lindo, 2018). However, which parts of the soil community contribute to driving HFA is not fully understood.
In the soil, decomposition is carried out by a complex biotic community consisting of organisms that differ in size and function, including fungi, bacteria, and micro- and mesofauna (Cadisch and Giller, 1997). Different decomposer taxa and size groups in a community complement each other in facilitating the process of decomposition. Larger-sized soil fauna feed on litter and break it down into smaller pieces, whereas microorganisms are responsible for the mineralization of organic residues, for example via the production of extra-cellular enzymes. The impact of different size fractions of macrofauna on decomposition was typically studied by varying the mesh size of litter bags (Perez et al., 2013; Wang et al., 2013). The role of smaller soil organisms, such as mesofauna and microorganisms, can be disentangled via filtration of soil solutions (e.g., Wagg et al., 2014). These approaches have shown that exclusion of soil mesofauna decreases decomposition rates (Wall et al.,

\footnotetext{
* Corresponding author.

E-mail address: liq@iae.ac.cn (Q. Li).
} 
2008). Interestingly, body size of the soil biota might cascade to HFA effects (Milcu and Manning, 2011). However, how the direction and magnitude of HFA effects depend on the presence of different size fractions of the biotic community, has rarely been studied.

Most studies showing positive HFA effects typically encompass reciprocal litter transplants from plant functional types that differ greatly (such as grasses versus trees) (Di Lonardo et al., 2018; Veen et al., 2015, 2018). However, HFA effects may also occur within mixed plant communities, because individual plants can create species-specific soil communities, including decomposer organisms (Bezemer et al., 2010; Kos et al., 2015). This local affinity between plants and decomposer organisms could result in HFA effects occurring at the scale of individual plants (Li et al., 2017). However, there are few studies using plant species that coexist in the same community to examine whether plant-specific decomposer communities decompose litter from the plant they are associated with faster than litter of other species that coexist in the same community (Fanin et al., 2016; Barbe et al., 2017). It is relevant to understand to what extent individual plants in mixed communities develop HFA effects, because the intensity of the HFA effect of different plants will affect the efficiency of nutrient cycling, ultimately affecting small-scale ecosystem processes such as interspecific competition and community succession (Freschet et al., 2012).

Here, we study how inoculation of different size fractions of the soil biotic community alters the composition of soil microbial communities and how this affects decomposition and HFA effects for two plant species that co-occur in mixed grassland communities. We carried out of a fullfactorial reciprocal litter transplant experiment in microcosms in a climate chamber and inoculated sterilized soil with size fractionated soil communities. Five size fractions of soil extractions were prepared: a watery soil solution sieved through (1) $850 \mu \mathrm{m}$, (2) $45 \mu \mathrm{m}$, (3) $20 \mu \mathrm{m}$, (4) $11 \mu \mathrm{m}$, and (5) $6 \mu \mathrm{m}$. Soil macrofauna, such as macroarthopods and earthworms, were removed by sieving at $850 \mu \mathrm{m}$. Mesofauna, such as Acaridae and Collembola, were removed at $45 \mu \mathrm{m}$. Microfauna, such as nematodes, were removed at $20 \mu \mathrm{m}$. We assumed that most soil fungi were excluded at $6 \mu \mathrm{m}$ which should contain predominantly microbiota such as bacteria (Wagg et al., 2014; Wang et al., 2019). We tested the hypotheses that: (1) Inoculation of soil communities that consist of small body size will decrease the abundance and composition of established bacterial and fungal communities in the soil, and consequently decrease litter decomposition. (2) HFA effects will be higher in soils inoculated with microorganisms and micro- and mesofauna than in soils inoculated with microorganisms alone, because specialization by decomposer communities towards litter types may occur across all size classes of organisms.

\section{Methods}

\subsection{Litter and soil collection}

Litter and soil samples were collected from a long-term grassland experiment located within a restored species-rich grassland at the Veluwe area, De Mossel, Ede, The Netherlands. The area (180 ha) was used to cultivate maize until 1996. The experimental site $(50 \mathrm{~m} \times 100$ m) was fenced in 1996 to avoid grazing by large vertebrate herbivores such as horses and cattle that roam freely in the area and consists of 20 experimental plots. The long-term experiment was initiated immediately upon abandonment of agricultural practices. After establishment in 1996, the plots have been mown once a year at the end of the season after which the aboveground biomass was removed from all plots (van der Putten et al., 2000; Bezemer et al., 2010). During the fall of 2015, recently senesced litter from Tanacetum vulgare and Jacobaea vulgaris was collected from all plots. We chose these species because they co-occur in all plots and have distinctly different chemical composition (Kos et al., 2015). For T. vulgare the litter consisted of dead leaves, while for J. vulgaris the litter consisted of dead leaf and stem material. Litter for each plant species within a plot was kept separately throughout the experiment. Litter was air-dried and cut into pieces of approximately 1 $\mathrm{cm}$.

For this study, seven plots from the field experiment with largest litter weight were selected as replicates. From each of these seven plots, litter from T. vulgare and J. vulgaris was sterilized using gamma irradiation ( $>25$ KGray, isotron, Ede, The Netherlands) to eliminate the effect of phyllosphere microbiome in testing the local adaption of the soil community. In May 2016, in each of the seven replicate plots, we selected three large rosettes of T. vulgare and J. vulgaris. We collected a soil block $(10 \times 10 \times 10 \mathrm{~cm})$ from the center of the focal rosette. In the laboratory, the roots were removed, and the samples from the three rosettes per plot for each species were homogenized so that there were 14 soil samples (7 replicate plots $\times 2$ species). The soil was sieved through a $1 \mathrm{~cm}$ mesh to remove stones and kept at $4{ }^{\circ} \mathrm{C}$.

\subsection{Microcosm decomposition experiment}

To determine the impact of different size fractions of the soil biotic community on decomposition, for each of the 14 soil samples, five community size fractions of soil extractions were prepared:

1) $850 \mu \mathrm{m}: 150 \mathrm{ml}$ phosphate buffer $\left(1 \mathrm{~g} \mathrm{KH}_{2} \mathrm{PO}_{4}\right.$ added to $1 \mathrm{~L}$ demiwater, after which the $\mathrm{pH}$ was adjusted to 6.5 with $\mathrm{NaOH}$ ) was added to $150 \mathrm{~g}$ soil (water: soil $=1: 1, \mathrm{w} / \mathrm{w}$ ) in a 1-L beaker. After firmly stirring for $30 \mathrm{~s}$ followed by $30 \mathrm{~s}$ resting, the soil solution was sieved through an $850 \mu \mathrm{m}$ sieve and stored in a glass container with a lid. Between each sample, the sieve was thoroughly rinsed with tap water.

2) $45 \mu \mathrm{m}$. The procedure described for (step 1) was followed. After sieving through the $850 \mu \mathrm{m}$ sieve, the soil solution was sieved through a $225 \mu \mathrm{m}$, a $75 \mu \mathrm{m}$ and then through a $45 \mu \mathrm{m}$ sieve.

3) $20 \mu \mathrm{m}$. The procedure described for (step 2) was followed. Except that $180 \mathrm{ml}$ phosphate buffer was added to $150 \mathrm{~g}$ soil to replenish the solution lost during the additional filtration step. After sieving through the $45 \mu \mathrm{m}$ sieve, the soil solution was filtered through 20-25 $\mu \mathrm{m}$ filter paper (Whatman Grade 41; diameter $90 \mathrm{~mm}$ ) using a Buchner funnel. Since the mesh size of filter paper was not exactly $20 \mu \mathrm{m}$, we subsequently filtered the solution through a $20 \mu \mathrm{m}$ sieve.

4) $11 \mu \mathrm{m}$. The procedure described for (step 3) was followed. After sieving through the $20 \mu \mathrm{m}$ sieve, the soil solution was filtered through $11 \mu \mathrm{m}$ filter paper (Whatman Grade 1; diameter $85 \mathrm{~mm}$ ) using a Buchner funnel.

5) $6 \mu \mathrm{m}$. The procedure described for (step 4) was followed. After sieving through the $11 \mu \mathrm{m}$ sieve, the soil solution was filtered through $6 \mu \mathrm{m}$ filter paper (Whatman Grade 3; diameter $90 \mathrm{~mm}$ ) using a Buchner funnel.

With this design we assumed that solutions sieved through $6 \mu \mathrm{m}$ should contain predominantly small microbiota such as bacteria and viruses (Wang et al., 2019). We further expected for the smallest sieving fractions: $20 \mu \mathrm{m}, 11 \mu \mathrm{m}$, and $6 \mu \mathrm{m}$ that the diversity of bacteria and fungi would also be reduced with declining pore size (Wagg et al., 2014).

We used a reciprocal litter transplant design where $T$. vulgare litter and $J$. vulgaris litter were decomposed in both T. vulgare soil and $J$. vulgaris soil across all size fractions of the soil biotic community. Litters were decomposed in the soils from the same field plot as where the litter was collected from and reciprocal transplants were carried out between $T$. vulgare and $J$. vulgaris soils originating from the same plot. Plastic containers $(10 \mathrm{~cm} \times 10 \mathrm{~cm} \times 5 \mathrm{~cm})$ were filled with $450 \mathrm{~g}$ gamma-sterilized soil collected from the field site where the litter and soil community also originated from. Each container then received 100 $\mathrm{ml}$ solution of a soil extraction. Containers were placed in a dark climate with a day-night temperature rhythm; $16 \mathrm{~h}$ at $20^{\circ} \mathrm{C}$ and $8 \mathrm{~h}$ at $14^{\circ} \mathrm{C}$. Relative humidity was 70\%. Seven days later, one litter bag (mesh size 1 $\mathrm{mm}$ ) filled with $2 \mathrm{~g}$ sterilized litter was put on top of the soil in each pot. Pots were weighed three times per week and water was added so that the 
soil moisture in each pot was kept at $20 \%$. Containers were harvested after 3 months and after 6 months, respectively. In total there were 280 containers ( 2 litter species $\times 2$ soil identities $\times 5$ community size fractions $\times 7$ replicate soils $\times 2$ harvest times). At each harvest, litter bags were removed from the containers and litter was gently washed over a $0.4 \mathrm{~mm}$ sieve, dried at $60^{\circ} \mathrm{C}$, and weighed. During the first harvest (after 3 months of decomposition), from each container a soil core was taken using a soil drill (1 cm diameter). A homogenized subsample of this soil was collected in an Eppendorf and stored at $-80^{\circ} \mathrm{C}$ to be used for molecular analysis of the bacterial and fungal communities.

\subsection{Molecular analysis of the soil microbial community}

To examine whether the inoculations after sieving at different size fractions, led to different microbial communities three months after inoculation, we determined the composition of the soil bacterial and fungal community using next generation sequencing. DNA was extracted from $0.50 \mathrm{~g}$ soil (for 4 replicates) using the PowerSoil DNA Isolation Kit (Mo Bio Laboratories, Carlsbad, CA, USA) following the manufacturer's protocol. The DNA quantity was measured using a Nanodrop spectrophotometer (Thermo Scientific, Hudson, NH, USA). Approximately 10 ng of DNA was used for a PCR. We used primers ITS4 and ITS9 targeting the ITS2 region of fungal genes (Ihrmark et al., 2012) and the primers 515F and 806R (tagged for individual samples) (Bates et al., 2011) targeting the V4 region of the 16Sr RNA gene in bacteria. The primers ITS9 and 806R were tagged with barcodes so that we could pool individual samples. Presence of PCR product was checked using agarose gel electrophoresis. The PCR products were purified using Agencourt AMPure XP magnetic beads (Beckman Coulter) with a PCR product/AMPure bead ratio of 1:0,7 and checked using agarose gel electrophoresis. Purified products were quantified with a Fragment Analyzer (Agilent) before equimolar pooling. Amplicons were sequenced using the Illumina MiSeq platform for $300 \mathrm{bp}$ paired-end reads. Bacterial sequences and fungal sequences were analyzed using PIPITS pipeline and Hydra pipeline, respectively (Gweon et al., 2015; de Hollander, 2017). In short, sequences were paired using VSEARCH and quality was filtered using standard parameters. For fungi, the ITS2 region was extracted using ITSx (Nilsson et al., 2015). Short reads were removed, and sequences were clustered based on a $97 \%$ similarity threshold using VSEARCH and chimeric sequences were removed by comparing with uchime database. The representative sequences of fungi were identified using the RDP classifier against the UNITE database (Kõljalg et al., 2013) and SINA classification with SILVA was used for bacteria.

Real-time PCR to quantify fungal and bacterial copy numbers was performed using sterile water and a mix from the Rotor-Gene SYBR Green PCR Kit (Qiagen) and primers ITS4ngs and ITS3mix (Tedersoo et al., 2014) for fungi and primers eub338 and eub518 (Fierer et al., 2005) for bacteria. T4 Gene 32 protein (Roche) was used to enhance the reaction and ensure similar amplification from all soils. The samples were analyzed on a Rotor-Gene 3000 machine (Gorbett Research, Sydney, Australia). The reaction mixtures were done using a pipeting robot (Gorbett Research, Sydney, Australia) in $20 \mu \mathrm{l}$ volume and contained $0.3 \mu \mathrm{M}$ of each primer, $0.25 \mu \mathrm{l} \mathrm{T} 4$ and $1.0-10.0 \mathrm{ng}$ template DNA. The cycling conditions for fungi were: $40 \mathrm{~s}$ at $95^{\circ} \mathrm{C}, 1 \mathrm{~min}$ at $55^{\circ} \mathrm{C}$ and $1 \mathrm{~min}$ at $72{ }^{\circ} \mathrm{C}$ and for bacteria $40 \mathrm{~s}$ at $95^{\circ} \mathrm{C}, 1 \mathrm{~min}$ at $53^{\circ} \mathrm{C}$ and $1 \mathrm{~min}$ at $72{ }^{\circ} \mathrm{C}$. Plasmids extracted from a pure fungal culture (Hypholoma vesicular) and a pure bacterial culture (Collimonas fungivorans), were serial diluted and used as a reference to calculate the copy numbers.

\subsection{Chemical analyses of litter}

A subsample of litter from each species in each plot was analyzed to determine the chemical properties of the litters. The litters were ground and carbon (C) and nitrogen (N) content were determined using an Element Analyzer (Flash 2000, Thermo Fisher Scientific, Bremen, Germany). Phosphate (P), potassium (K) and trace elements (Ca, Mg, S, Fe,
$\mathrm{Mn}, \mathrm{Cu}$ and $\mathrm{Zn}$ ) were determined using inductively coupled plasmaoptical emission spectrophotometry (ICP-OES) (iCAP 6500 DUO, Thermo Scientific, Cambridge, UK) after closed digestion using a microwave oven (Hansen et al., 2013). Lignin and cellulose content were determined after methanol-chloroform extractions and hydrolysis (Rowland and Roberts, 1994).

\subsection{Data analysis}

Mass loss in the microcosm experiment was analyzed using a general linear mixed model (GLMM) with harvest time (three months and six months), litter species (T. vulgare/J. vulgaris litter), soil identity (T. vulgare/J. vulgaris soil), community size fractions $(6,11,20,45,850$ $\mu \mathrm{m})$ as fixed factors and all possible interactions among those factors. Field plot identity was used as a random factor. Since the GLMM revealed a significant interaction between litter species and harvest time on mass loss (see results), we also used GLMMs to test how soil identity, community size fractions and their interaction affected litter mass loss for each litter species and at both harvest times.

We computed the home-field advantage index (HFA index) for mass loss data based on Ayres et al. (2009) using the following functions:

$A_{R M L_{a}}=\frac{A_{a}}{A_{a}+B_{a}} \times 100$

Where, Aa and Ba represents the mass loss of litter A and B at soil a, respectively. The same uppercase and lowercase letters indicate that litter decomposed at the home soil (i.e. that litter and soil were from the same plant species). $A_{\text {RMLa }}$ represents the relative mass loss of litter $A$ at soil a.

The HFA index was then calculated as:

$H F A \operatorname{index}(\%)=\left[\left(\frac{A_{R M L_{a}}+B_{R M L_{b}}}{2}\right) /\left(\frac{A_{R M L_{b}}+B_{R M L_{a}}}{2}\right)\right] \times 100-100$

The HFA index represents the percentage higher mass loss of litter when it decomposes at home versus away for both species (A and B). Linear regression analysis was used to examine the relationship between the HFA index and community size fractions at two harvest time. Plot identification was used as a random factor. We used a one-sample $t$-test to test for significant deviations from zero.

Analyses of the bacterial and fungal sequence data: Sequencing of several samples failed due to extremely low sequences reads (total reads less than 100), and these were excluded from analysis. There were 78 sequenced samples for bacteria and 80 sequenced samples for fungi that were induced in the analysis. To account for differences in sequencing depth, relative abundances of sequences were calculated. Relative data were analyzed and the range of number of reads per sample was 14652-97481 for bacteria and 1434 to 46115 for fungi. OTUs with a read frequency of less than $0.02 \%$ for bacteria and $0.1 \%$ for fungi were removed to normalize the data (due to a positive effect of number of sequence reads per sample and OTU richness in the data). Bacterial and fungal richness (number of OTUs) and abundance (16S and ITS copies, Real-time PCR results) were analyzed using GLMMs with litter species, soil identity and community size fractions and their interactions as fixed factors. Plot identity was used as a random factor. Bacterial and fungal community composition was visualized by principal component analysis (PCA) based on OTU composition in CANOCO Version 5.0 (Plant Research International, Wageningen, The Netherlands). PERMANOVA analysis was used to determine whether bacterial and fungal community composition were significantly influenced by litter species, soil identity and size of the soil community using Bray-Curtis distance with package vegan in $R$. To test how our treatments affected the relative abundance of each bacterial and fungal classification level (phylum, class, order, family, genus and species), we used GLMMs with their relative abundance as a response variable, litter species, soil identity, community size fractions and their interactions as fixed factors, and field plot identity as 
a random factor. FunGuild was used to assign potential functions of fungal OTUs and the output of this file was compared (curated) against an inhouse database on fungal functions (Nguyen et al., 2016; Hannula et al., 2017). The significance of the relationship between litter mass loss, HFA effect and microbial indicators for each harvest time was analyzed using a Pearson correlation. For general linear mixed models, we tested the homogeneity of the variances using a Fligner-Killeen test and the residuals for normality with a Shapiro-Wilk normality test. Fungal abundance data were ln-transformed to improve normality. Spearman correlations were used for correlation analysis of data that does not conform to normality and a Bonferroni correction was applied for multiple comparison tests. All statistical analyses were performed in $\mathrm{R}$ version 3.5.1 ( $\mathrm{R}$ Core Team, 2018).

\section{Results}

\subsection{Effects on soil bacterial and fungal communities}

After three months of decomposition, bacterial abundance and fungal richness in the soil was significantly affected by the size of the soil community (Fig. 1). Richness of both groups of soil organisms decreased significantly with decreasing size fractions, but the decline was much stronger for fungi (Fig. 1, Table S1). Bacterial abundance increased slightly with decreasing size fractions while fungal abundance did not differ across the different size fractions (Fig. 1). Bacterial and fungal community composition were significantly influenced by soil identity and size fractions of the soil biotic community, but not by litter species (Table 1 and Fig. 2). Across all the treatments, the dominant bacterial classes (the ten with the highest relative abundance) were: Alphaproteobacteria, Gammaproteobacteria, Actinobacteria, Sphingobacteriia, Ktedonobacteria, Bacteroidia, Gemmatimonadetes, Bacilli, Deltaproteobacteria, and a group of Unclassified bacteria (Fig. 3). The dominant fungal families (ten with the highest relative abundance) were:
Tremellomycetes, Sordariomycetes, Eurotiomycetes, Dothideomycetes, Mortierellomycotina, Leotiomycetes, Agaricomycetes, Orbiliomycetes, Spizellomycetes, and a group of Unclassified fungi (Fig. 3). More information about the litter quality relative abundance of bacterial and fungal groups can be found in the supplementary information (Fig. S1, Tables S2, S3, S4).

\subsection{Effects on litter decomposition}

Litter mass loss was significantly affected by harvest time, litter species, size fractions of the soil biotic community, the interaction between harvest time and litter species and the interaction between litter species and soil identity (Table 2). T. vulgare litter decomposed faster than $J$. vulgaris litter. Decomposition rates declined over time, and litter mass loss during the first three months $(20.2 \%)$ was much larger than during the next three months (5.4\%, Fig. 4). T. vulgare litter decomposed faster in T. vulgare soil after 3 months (Fig. 4). J. vulgaris and T. vulgare litter decomposed faster in big size fractions of the soil biotic community in the 3 months and 6 months, respectively (Fig. 4).

\subsection{Effects on HFA}

After three months of decomposition, the HFA index was positive in the pots inoculated with the smallest size fractions of the soil biotic community. Moreover, the HFA index increased with decreasing size fractions of the soil biotic community (Fig. 5). After six months there were no positive HFA effects and there was no relationship between the inoculated size fractions and the HFA index (Fig. 5). The dissimilarity in bacterial communities between home and away soils was positively related to the HFA index at three months (Fig. 6). The fungal community dissimilarity between home and away soils was positively related to the HFA index at six months (Fig. 6).
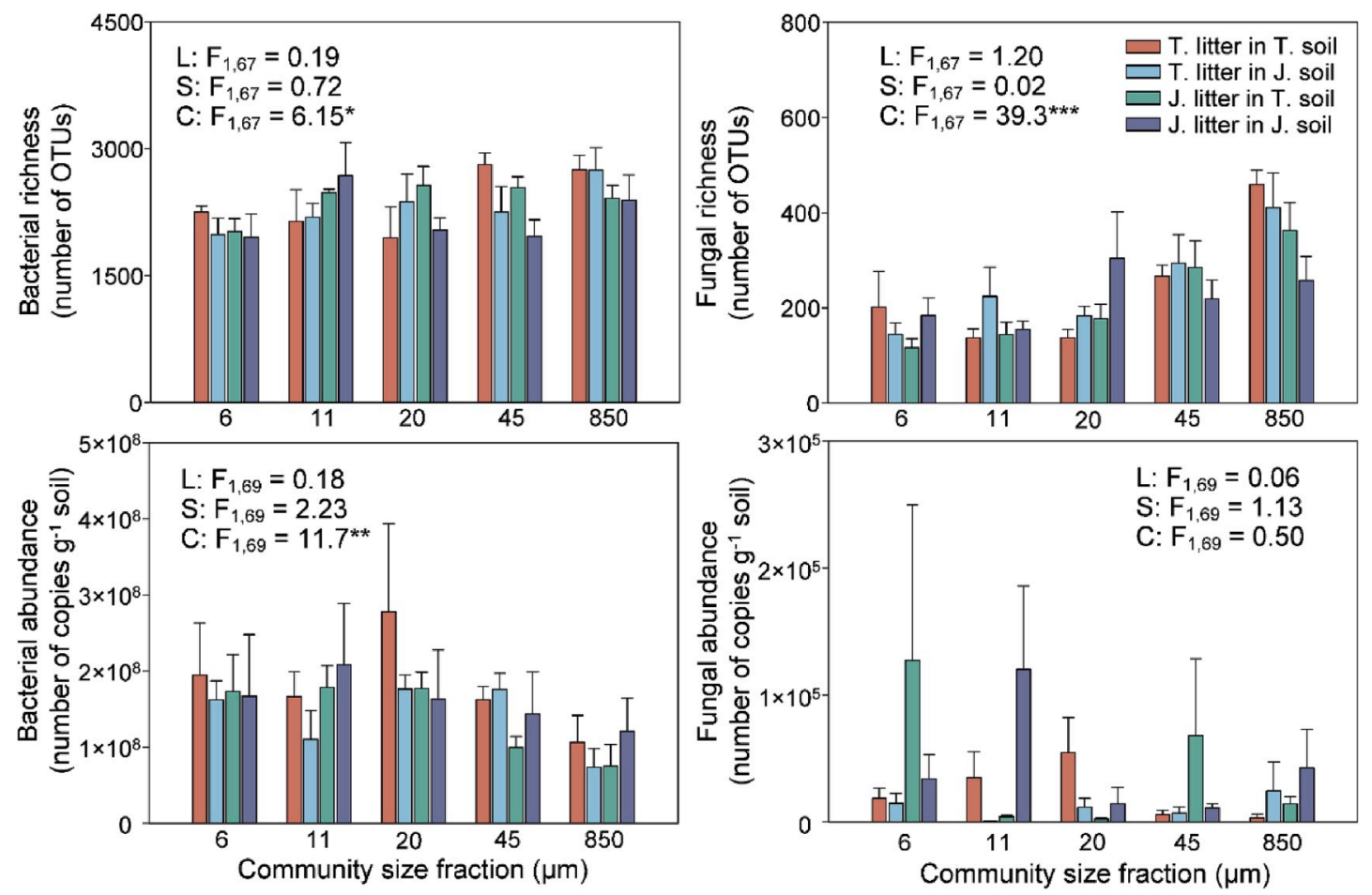

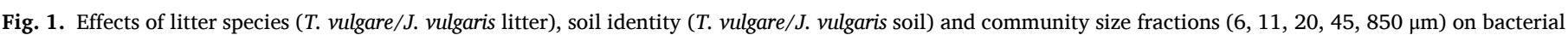

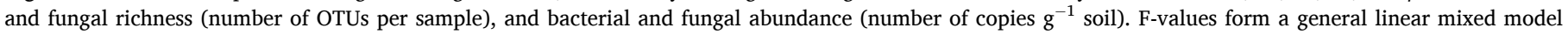

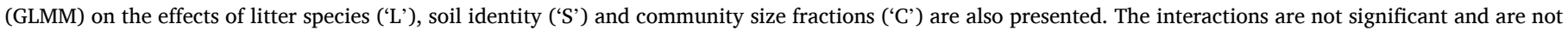
shown. ${ }^{*} P<0.05 ;{ }^{*} * P<0.01 ;{ }^{*} *{ }^{*} P<0.001$. 
Table 1

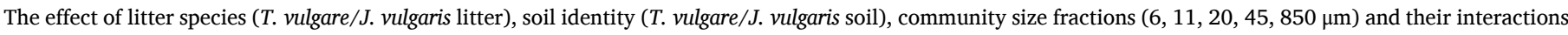

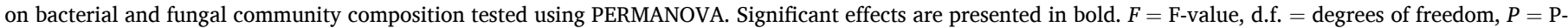
value, $\%=$ percentage explained variation.

\begin{tabular}{|c|c|c|c|c|c|c|c|c|}
\hline & \multicolumn{4}{|c|}{ Bacterial community } & \multicolumn{4}{|c|}{ Fungal community } \\
\hline & $F$ & d.f. & $P$ & $\%$ & $F$ & d.f. & $P$ & $\%$ \\
\hline Litter species & 0.719 & 1,70 & 0.866 & 0.9 & 0.692 & 1,72 & 0.836 & 0.8 \\
\hline Soil identity & 2.220 & 1,70 & 0.020 & 2.8 & 3.000 & 1,72 & 0.005 & 3.4 \\
\hline Community size fraction & 3.223 & 1,70 & 0.005 & 4.1 & 6.724 & 1,72 & 0.005 & 7.8 \\
\hline Litter species $\times$ Soil identity & 0.753 & 1,70 & 0.830 & 1.0 & 0.723 & 1,72 & 0.771 & 0.8 \\
\hline Litter species $\times$ Community size fraction & 0.601 & 1,70 & 0.945 & 0.8 & 0.858 & 1,72 & 0.612 & 1.0 \\
\hline Soil identity $\times$ Community size fraction & 0.854 & 1,70 & 0.672 & 1.1 & 1.135 & 1,72 & 0.264 & 1.3 \\
\hline 3-way interaction & 0.852 & 1,70 & 0.647 & 1.1 & 0.827 & 1,72 & 0.637 & 1.0 \\
\hline
\end{tabular}

\section{J. vulgaris soil bacterial community}

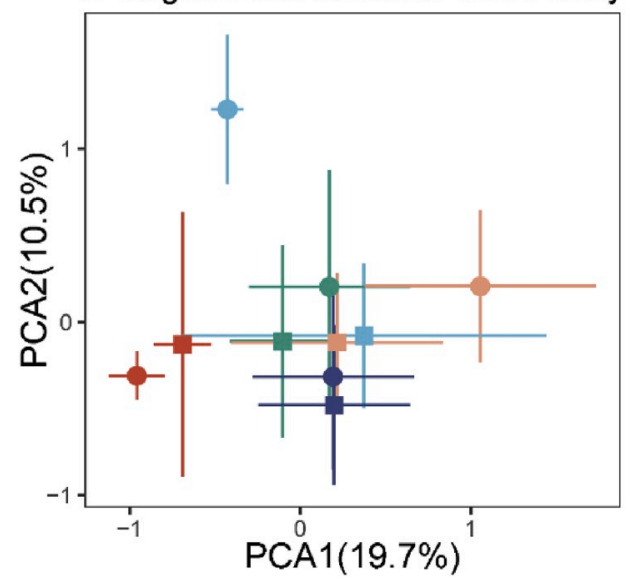

J. vulgaris soil fungi community

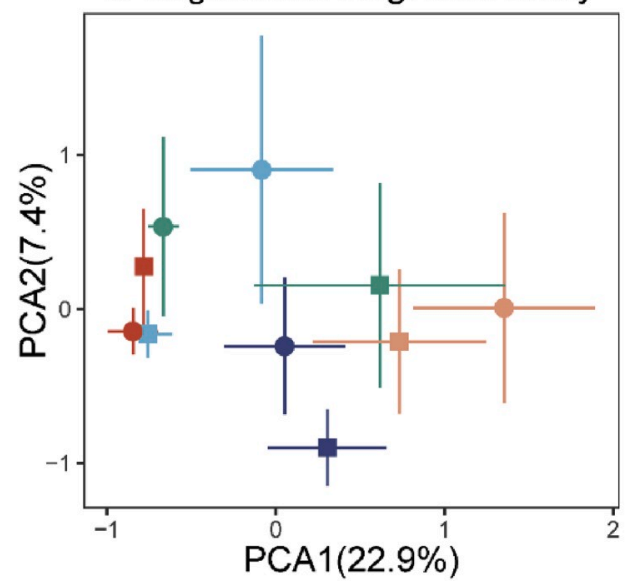

\section{$T$. vulgare soil bacterial community}
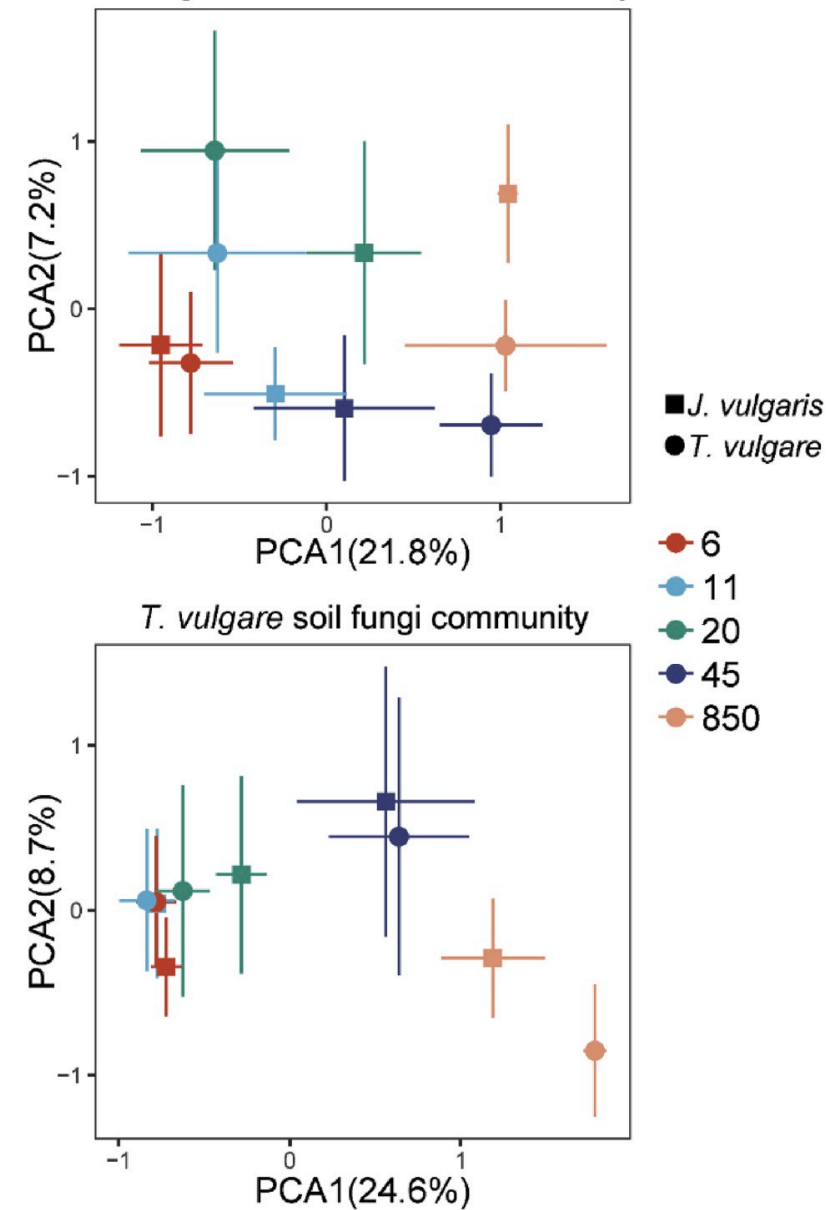

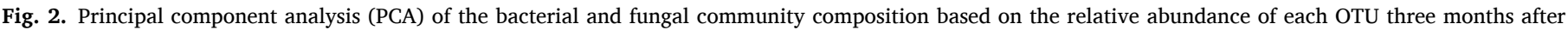

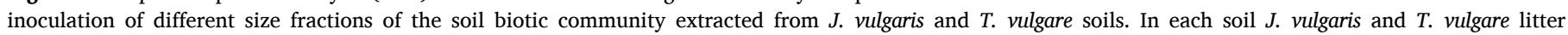
was decomposed.

\section{Discussion}

\subsection{Effects of size fractions on soil bacterial and fungal communities and litter decomposition}

Consistent with our first hypothesis, inoculation with different size fractions of the soil biotic community resulted in shifts in the composition and diversity of the soil microbial community three months after inoculation, and changes in the soil biotic composition altered the decomposition of plant litters. This is in line with previous findings showing that the body size of soil organisms provides a good functional classification of these organisms because it correlates with metabolic rate, generation time, population density, and food size (Bradford et al., 2002). Also, in line with previous findings (Wagg et al., 2014), we found that the bacterial and fungal richness decreased with decreasing size fractions of the soil biotic community. Changes in soil biodiversity and soil community composition are known to impact decomposition processes (Bardgett and van der Putten, 2014). Our results show that litter mass loss decreased slightly with decreasing size fractions used for the inoculum. These results indicate that a loss of diversity of soil microorganisms can result in a loss of functioning and a greater diversity of soil microorganisms enhances litter breakdown (Hättenschwiler et al., 2011; Wagg et al., 2014).

Addition of entire soil communities (i.e. whole soil inoculum added 


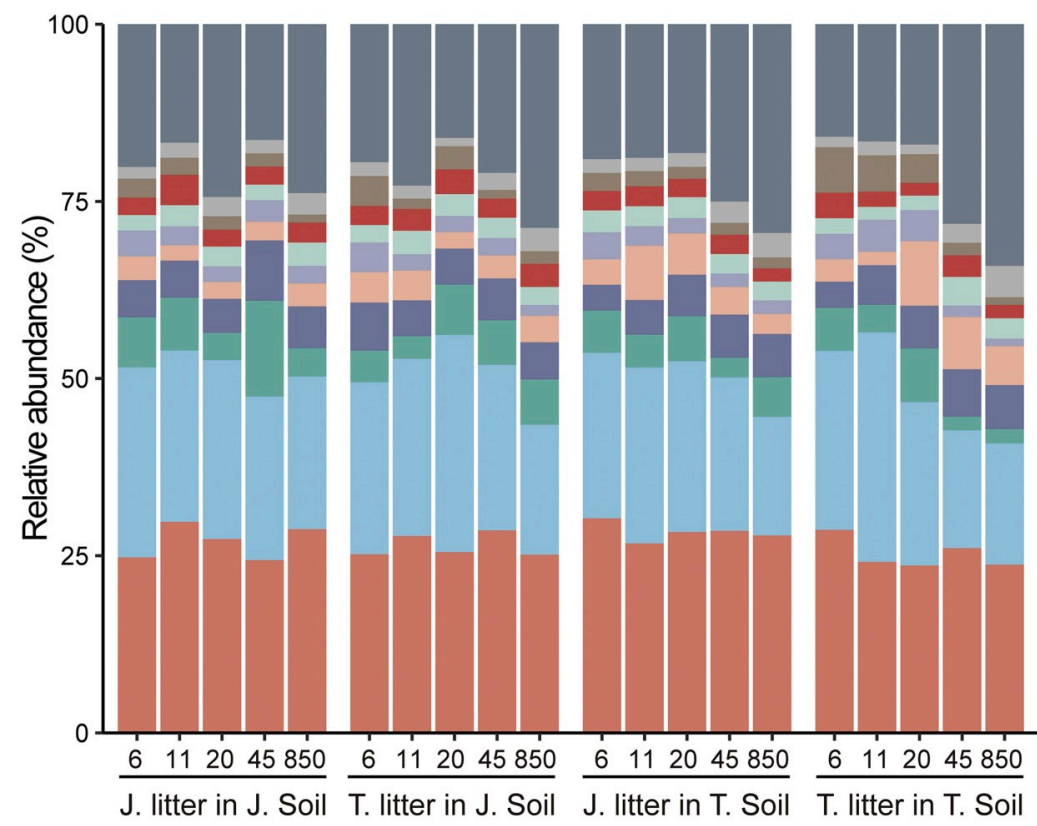

Bacterial class

\begin{tabular}{ll}
\hline Other \\
Deltaproteobacteria \\
Unclassified \\
\hline Bacilli \\
Gemmatimonadetes \\
Bacteroidia \\
Ktedonobacteria \\
Sphingobacteriia \\
Actinobacteria \\
Gammaproteobacteria \\
Alphaproteobacteria
\end{tabular}

Fungal class

\begin{tabular}{|l|}
\hline Other \\
\hline Spizellomycetes \\
\hline Orbiliomycetes \\
\hline Agaricomycetes \\
\hline Leotiomycetes \\
\hline Mortierellomycotina \\
\hline Dothideomycetes \\
\hline Unidentified \\
\hline Eurotiomycetes \\
Sordariomycetes \\
Tremellomycetes
\end{tabular}

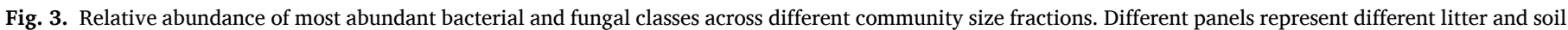
treatments. Within each panel, individual bars represent different community size fractions. The classes with low relative abundances were merged into 'other'.

to sterile soil), potentially with mesofauna such as collembola and enchytraeids to sterilized soil, resulted in higher decomposition rates than the average values we obtained for addition of watery and filtered extracts (Fig. S2). Although we did not quantify the abundance and composition of micro- and mesofauna in the soil in the present study, our results confirm that soil fauna contribute to litter mass loss which is not surprising as they play a key role in fragmenting and ingesting litter (Wall et al., 2008; Zhang et al., 2015; Lin et al., 2019a).

\subsection{Effects of size fractions on home-field advantage}

In contrast to our second hypothesis, we found that the HFA effect was positive and higher with decreasing size fractions of the soil biotic community at the first harvest, which suggests that soil microorganisms may be more specialized to specific resources than larger soil organisms. Soil microorganisms act on a very local scale and respond to available substrates quickly via adaptation or changes in community composition
(Strickland et al., 2009; van der Wal et al., 2013; Li et al., 2019). As a result, specialized microbial decomposer communities that accelerate the breakdown of local litter can develop if the same litter type is consistently present (Keiser et al., 2011). In our experiment, we observed that the increasing abundance of some specific bacteria and fungi may have promoted the generation of home-field advantage effects, as the relative abundance increases of specific bacteria and fungi, such as Xanthomonadales and Cutaneotrichosporon (Fig. S3, Tables S3 and S4), increased with decreasing size fractions. The relative abundance of the Cutaneotrichosporon, was also significantly different between the two soils (Table S4). The finding that bacterial- and fungal-mediated HFA effects may be driven by some specific taxa, rather than by whole microbial communities is in line with recent work that showed that the magnitude of HFA effects was only explained by particular groups of fungi (Lin et al., 2019b; Veen et al., 2019). Predators can contribute to rarity of bacterial taxa in the field, and can alter the functioning of soil microbiomes (Wardle et al., 1995; John et al., 2000; 
Table 2

Results from a general linear mixed model testing the influence of harvest time, litter species (T. vulgare/J. vulgaris litter), soil identity (T. vulgare/J. vulgaris soil) and community size fractions $(6,11,20,45,850 \mu \mathrm{m})$ and their interactions on litter mass loss in the microcosm experiment. $F=$ F-value, d.f. $=$ degrees of freedom, $P=\mathrm{P}$-value. Values in bold are significant at $P<0.05$.

\begin{tabular}{llll}
\hline & $F$ & d.f. & $P$ \\
\hline Harvest time & $\mathbf{9 0 . 4 6}$ & $\mathbf{1 , 2 5 4}$ & $<\mathbf{0 . 0 0 1}$ \\
Litter species & $\mathbf{3 5 3 . 4 1}$ & $\mathbf{1 , 2 5 4}$ & $<\mathbf{0 . 0 0 1}$ \\
Soil identity & $\mathbf{3 . 9 5}$ & $\mathbf{1 , 2 5 4}$ & $\mathbf{0 . 0 4 8}$ \\
Community size fraction & $\mathbf{8 . 1 5}$ & $\mathbf{1 , 2 5 4}$ & $\mathbf{0 . 0 0 5}$ \\
Harvest time $\times$ litter species & $\mathbf{1 1 . 7 6}$ & $\mathbf{1 , 2 5 4}$ & $<\mathbf{0 . 0 0 1}$ \\
Harvest time $\times$ Soil identity & 0.01 & 1,254 & 0.938 \\
Harvest time $\times$ Community size fractions & 1.02 & 1,254 & 0.314 \\
Litter species $\times$ Soil identity & 1.07 & 1,254 & 0.301 \\
Litter species $\times$ Community size fractions & 0.13 & 1,254 & 0.718 \\
Soil identity $\times$ Community size fractions & 2.45 & 1,254 & 0.119 \\
Harvest time $\times$ Litter species $\times$ Soil identity & 0.13 & 1,254 & 0.716 \\
Harvest time $\times$ Litter species $\times$ Community size & 1.32 & 1,254 & 0.251 \\
$\quad$ fractions & & & \\
Harvest time $\times$ Soil identity $\times$ Community size & 0.52 & 1,254 & 0.471 \\
$\quad$ fractions & & & \\
Litter species $\times$ Soil identity $\times$ Community size & 0.20 & 1,254 & 0.656 \\
$\quad$ fractions & & & \\
4-way interaction & 2.57 & 1,254 & 0.110 \\
\hline
\end{tabular}
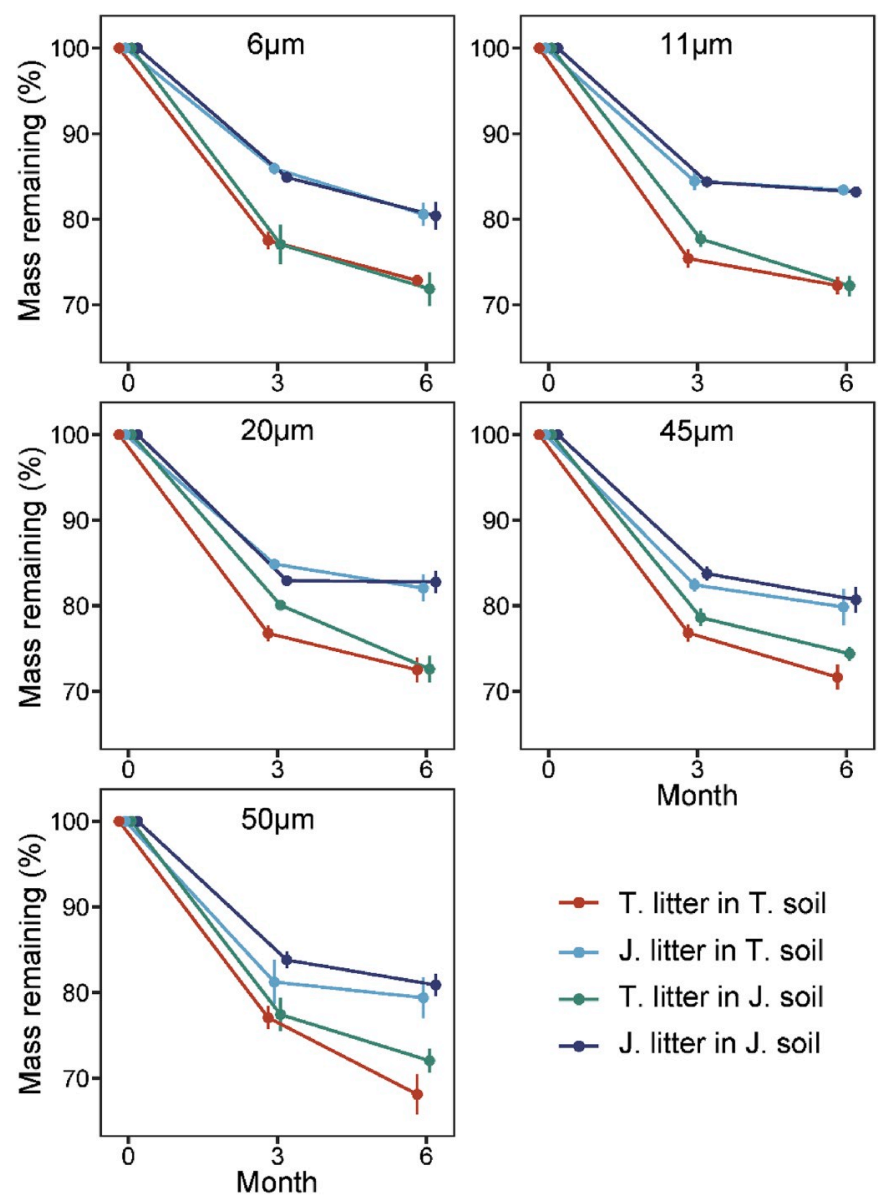

Fig. 4. Mass remaining (\%) of T. vulgare and $J$. vulgaris litter in the microcosm experiment. Presented are means \pm SE for each community size fractions $(6,11$, $20,45,850 \mu \mathrm{m})$ at two harvest times (three months and six months).

Thakur and Geisen, 2019). This may explain why the HFA effect increased after we removed larger sized soil organisms because in the absence of e.g. larger sized predators, the abundance of some specialized microbes may increase and these may then play an important role in the decomposition process. Further studies should examine the importance of HFA effects when such predators are present.

Litters with very distinct decomposer communities in their home soil, may generate stronger HFA effects than when home and away soils have a similar composition (Veen et al., 2015). We found that the magnitude of HFA effects relates to the dissimilarity of bacterial communities in home and away soils. This was not the case for fungal communities after three months of decomposition, but increasing dissimilarity in the fungal community (measured at three months) between home and away soils related to stronger HFA effects (measured as litter decomposition after six months). This finding suggests that both bacterial and fungal communities play a role in HFA effects, but that their specific roles may be visible during different stages of litter decomposition (Güsewell and Gessner, 2009; Purahong et al., 2019). Bacteria and fungi differ greatly in growth strategies and resources competitiveness and this may explain these results (Kaiser et al., 2014). During the early stages of litter decomposition, an increase in the quality of resources could increase the growth and composition of (fast growing) bacteria. In contrast, most fungi have low nutritional needs and special functions such as decompose recalcitrant matter, and may thus be better adapted to later decomposition stages with poor-quality substrates. In our experiment, we only measured bacterial and fungal communities after three months of litter decomposition. It is important to note that bacterial and fungal composition and the degree of specialized effects may vary during the process of litter decomposition (Aneja et al., 2006; van der Wal et al., 2015; Purahong et al., 2016). Future work should examine in more detail how bacterial and fungal communities change over time to better understand the roles of microbes in driving HFA effects at different stages of the most litter mass breakdown (Fanin et al., 2016). In addition, recent work had indicated that resident communities on litters (e.g., originating from phyllosphere communites) may play a key role in driving HFA (Veen et al., 2019). We used sterilized litter because the elimination of these resident litter communities allows for testing local adaptation of the soil community. However, to fully understand how decomposers drive HFA, it will be essential that future work untangles how resident litter communities affect decomposition and HFA (Austin et al., 2014; Veen et al., 2019).

Our findings are in contrast with previous studies which showed that HFA effects were similar for all size classes of decomposers (e.g. Milcu and Manning, 2011; St John et al., 2011). Those studies typically tested HFA effects under field conditions using litter bags with different mesh sizes, and included larger soil fauna such as earthworms, which appeared to play an important role in HFA effects (Milcu and Manning, 2011). In contrast, we used size fractionation of the soil biotic community, excluded larger fauna, performed the experiment in the laboratory and focused on the micro/meso scale. These experimental differences may explain the contrasting findings, but also many other factors, for example, abiotic environmental conditions may affect soil microbes, fauna and decomposition rates (Vivanco and Austin, 2008), thereby leading to different results.

\section{Conclusions}

Our study shows that with decreasing size fractions of the soil biotic community, microbial richness decreases, while the microbial abundance increases. Litter mass loss decreased slightly with decreasing soil decomposer community size, whereas HFA effects increased at the first harvest and were negatively related to the microbial richness. Our results, therefore, suggest that soil microorganisms can be specialized to decompose specific resources, thus promoting HFA effects, but that their specific roles may be visible during different stages of litter decomposition.

\section{Declaration of competing interest}

The authors declare that they have no known competing financial 

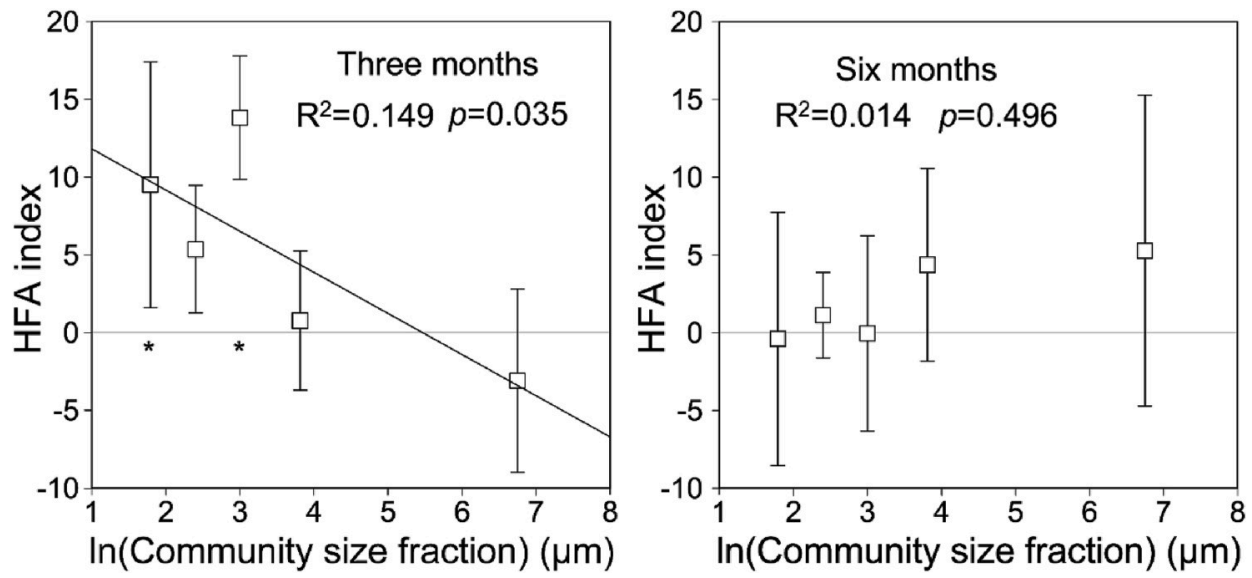

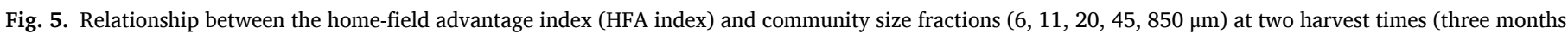
and six months). $\mathrm{R}^{2}$ and $\mathrm{P}$-value are also presented. Asterisks indicate significant differences from zero $(P<0.05)$.
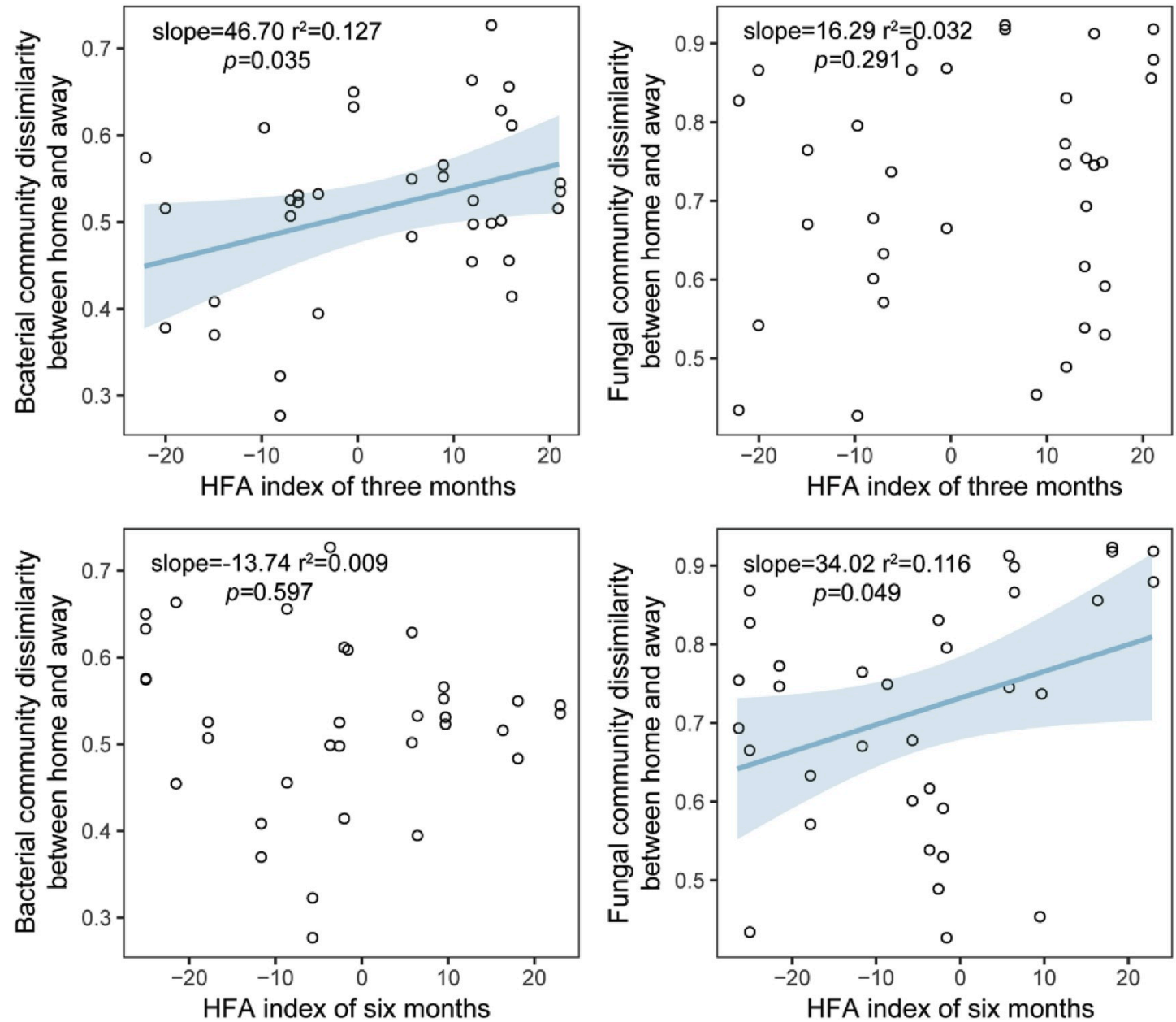

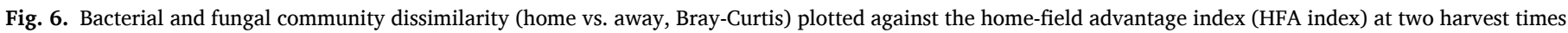
(three months and six months). Relationship are tested using linear regression analyses.

interests or personal relationships that could have appeared to influence the work reported in this paper.

\section{Acknowledgements}

This research was supported by the Netherlands Organisation for Scientific Research (NWO VICI grant no. 865.14.006), the National
Natural Science Foundation of China (Grant No. 41877047) and K. C. Wong Education Foundation (GJTD-2019-10). GFV was supported by a VENI grant from the Netherlands Organisation for Scientific Research (no. 863.14.013). We thank Roel Wagenaar and Martijn van der Sluijs for their help in the experiments performed. The authors declare no conflict of interest. 
Appendix A. Supplementary data

Supplementary data to this article can be found online at https://doi. org/10.1016/j.soilbio.2020.107783.

\section{References}

Aneja, M.K., Sharma, S., Fleischmann, F., Stich, S., Heller, W., Bahnweg, G., Munch, J.C., Schloter, M., 2006. Microbial colonization of beech and spruce litter-influence of decomposition site and plant litter species on the diversity of microbial community. Microbial Ecology 52, 127-135.

Austin, A.T., Vivanco, L., Gonzalez-Arzac, A., Perez, L.I., 2014. There's no place like home? An exploration of the mechanisms behind plant litter- decomposer affinity in terrestrial ecosystems. New Phytologist 204, 307-314.

Ayres, E., Steltzer, H., Simmons, B.L., Simpson, R.T., Steinweg, J.M., Wallenstein, M.D., Mellor, N., Parton, W.J., Moore, J.C., Wall, D.H., 2009. Home-field advantage accelerates leaf litter decomposition in forests. Soil Biology and Biochemistry 41, 606-610.

Barbe, L., Jung, V., Prinzing, A., Bittebiere, A.K., Butenschoen, O., Mony, C., 2017 Functionally dissimilar neighbors accelerate litter decomposition in two grass species. New Phytologist 214, 1092-1102.

Bardgett, R.D., van der Putten, W.H., 2014. Belowground biodiversity and ecosystem functioning. Nature 515, 505.

Bates, S.T., Berg-Lyons, D., Caporaso, J.G., Walters, W.A., Knight, R., Fierer, N., 2011. Examining the global distribution of dominant archaeal populations in soil. The ISME Journal 5, 908.

Bezemer, T.M., Fountain, M.T., Barea, J.M., Christensen, S., Dekker, S.C., Duyts, H., van Hal, R., Harvey, J.A., Hedlund, K., Maraun, M., Mikola, J., Mladenov, A.G., Robin, C., de Ruiter, P.C., Scheu, S., Setälä, H., Šmilauer, P., van der Putten, W.H., 2010. Divergent composition but similar function of soil food webs of individual plants: plant species and community effects. Ecology 91, 3027-3036.

Bradford, M.A., Jones, T.H., Bardgett, R.D., Black, H.I.J., Boag, B., Bonkowski, M., Cook, R., Eggers, T., Gange, A.C., Grayston, S.J., Kandeler, E., McCaig, A.E., Newington, J.E., Prosser, J.I., Setala, H., Staddon, P.L., Tordoff, G.M., Tscherko, D., Lawton, J.H., 2002. Impacts of soil faunal community composition on model grassland ecosystems. Science 298, 615-618.

Bradford, M.A., Veen, G.F., Bonis, A., Bradford, E.M., Classen, A.T., Cornelissen, J.H.C., Crowther, T.W., De Long, J.R., Freschet, G.T., Kardol, P., Manrubia-Freixa, M., Maynard, D.S., Newman, G.S., Logtestijn, R.S.P., Viketoft, M., Wardle, D.A., Wieder, W.R., Wood, S.A., van der Putten, W.H., 2017. A test of the hierarchical model of litter decomposition. Nature Ecology \& Evolution 1, 1836-1845.

Cadisch, G., Giller, K.E., 1997. Driven by nature: plant litter quality and decomposition. $\mathrm{CAB}$ international.

de Hollander, M. (2017, September 4). nioo-knaw/hydra: 1.3.3 (Version 1.3.3). Zenodo

Di Lonardo, D.P., Manrubia, M., De Boer, W., Zweers, H., Veen, G.F., van der Wal, A., 2018. Relationship between home-field advantage of litter decomposition and priming of soil organic matter. Soil Biology and Biochemistry 126, 49-56.

Fanin, N., Fromin, N., Bertrand, I., 2016. Functional breadth and home-field advantage generate functional differences among soil microbial decomposers. Ecology 97, 1023-1037.

Freschet, G.T., Aerts, R., Cornelissen, J.H., 2012. Multiple mechanisms for trait effects on litter decomposition: moving beyond home-field advantage with a new hypothesis. Journal of Ecology 100, 619-630.

Fierer, N., Jackson, J.A., Vilgalys, R., Jackson, R.B., 2005. Assessment of soil microbial community structure by use of taxon-specific quantitative PCR assays. Applied and Environmental Microbiology 71, 4117-4120.

Gholz, H.L., Wedin, D.A., Smitherman, S.M., Harmon, M.E., Parton, W.J., 2000. Longterm dynamics of pine and hardwood litter in contrasting environments: toward a global model of decomposition. Global Change Biology 6, 751-765.

Güsewell, S., Gessner, M.O., 2009. N : P ratios influence litter decomposition and colonization by fungi and bacteria in microcosms. Functional Ecology 23, 211-219.

Gweon, H.S., Oliver, A., Taylor, J., Booth, T., Gibbs, M., Read, D.S., Griffiths, R.I., Schonrogge, K., 2015. PIPITS: an automated pipeline for analyses of fungal internal transcribed spacer sequences from the Illumina sequencing platform. Methods in Ecology and Evolution 6, 973-980.

Hannula, S.E., Morriën, E., de Hollander, M., van der Putten, W.H., van Veen, J.A., de Boer, W., 2017. Shifts in rhizosphere fungal community during secondary succession following abandonment from agriculture. The ISME Journal 11, 2294.

Hansen, T.H., de Bang, T.C., Laursen, K.H., Pedas, P., Husted, S., Schjoerring, J.K., 2013 Multielement plant tissue analysis using ICP spectrometry. In: Maathuis, F.J.M. (Ed.), Plant Mineral Nutrients: Methods and Protocols. Humana Press, Totowa, NJ, pp. 121-141.

Hättenschwiler, S., Fromin, N., Barantal, S., 2011. Functional diversity of terrestrial microbial decomposers and their substrates. Comptes Rendus Biologies 334, 393-402.

Hunt, H., Ingham, E., Coleman, D., Elliott, E., Reid, C., 1988. Nitrogen limitation of production and decomposition in prairie, mountain meadow, and pine forest. Ecology 69, 1009-1016.

Ihrmark, K., Bödeker, I.T.M., Cruz-Martinez, K., Friberg, H., Kubartova, A., Schenck, J., Strid, Y., Stenlid, J., Brandström-Durling, M., Clemmensen, K.E., Lindahl, B.D., 2012 New primers to amplify the fungal ITS2 region - evaluation by 454-sequencing of artificial and natural communities. FEMS Microbiology Ecology 82, 666-677.

John, D., Erick, J.G.Z., Liliane, R., 2000. Food preferences of a fungal-feeding Aphelenchoides species. Nematology 2, 223-230.
Kaiser, C., Franklin, O., Dieckmann, U., Richter, A., 2014. Microbial community dynamics alleviate stoichiometric constraints during litter decay. Ecology Letters 17, 680-690.

Keiser, A.D., Strickland, M.S., Fierer, N., Bradford, M.A., 2011. The effect of resource history on the functioning of soil microbial communities is maintained across time. Biogeosciences 8, 1477-1486.

Kõljalg, U., Nilsson, R.H., Abarenkov, K., Tedersoo, L., Taylor, A.F., Bahram, M., Bates, S. T., Bruns, T.D., Bengtsson-Palme, J., Callaghan, T.M., 2013. Towards a unified paradigm for sequence-based identification of fungi. Molecular Ecology 22, 5271-5277.

Kos, M., Bukovinszky, T., Mulder Patrick, P.J., Bezemer, T.M., 2015. Disentangling above- and belowground neighbor effects on the growth, chemistry, and arthropod community on a focal plant. Ecology 96, 164-175.

Li, Y.B., Bezemer, T.M., Yang, J.J., Lü, X.T., Li, X.Y., Liang, W.J., Han, X.G., Li, Q., 2019. Changes in litter quality induced by $\mathrm{N}$ deposition alter soil microbial communities. Soil Biology and Biochemistry 130, 33-42.

Li, Y.B., Li, Q., Yang, J.J., Lü, X.T., Liang, W.J., Han, X.G., Bezemer, T.M., 2017. Homefield advantages of litter decomposition increase with increasing $\mathrm{N}$ deposition rates: a litter and soil perspective. Functional Ecology 31, 1792-1801.

Lin, D.M., Wang, F., Fanin, N., Pang, M., Dou, P.P., Wang, H.J., Qian, S.H., Zhao, L., Yang, Y.C., Mi, X.C., Ma, K.P., 2019a. Soil fauna promote litter decomposition but do not alter the relationship between leaf economics spectrum and litter decomposability. Soil Biology and Biochemistry 136, 107519.

Lin, D.M., Pang, M., Fanin, N., Wang, H.J., Qian, S.H., Zhao, L., Yang, Y.C., Mi, X.C., Ma, K.P., 2019b. Fungi participate in driving home-field advantage of litter decomposition in a subtropical forest. Plant and Soil 434, 467-480.

Milcu, A., Manning, P., 2011. All size classes of soil fauna and litter quality control the acceleration of litter decay in its home environment. Oikos 120, 1366-1370.

Nguyen, N.H., Song, Z., Bates, S.T., Branco, S., Tedersoo, L., Menke, J., Schilling, J.S., Kennedy, P.G., 2016. FUNGuild: an open annotation tool for parsing fungal community datasets by ecological guild. Fungal Ecology 20, 241-248.

Nilsson, R.H., Tedersoo, L., Ryberg, M., Kristiansson, E., Hartmann, M., Unterseher, M., Porter, T.M., Bengtsson-Palme, J., Walker, D.M., de Sousa, F., Gamper, H.A., Larsson, E., Larsson, K.-H., Kõljalg, U., Edgar, R.C., Abarenkov, K., 2015. A comprehensive, automatically updated fungal ITS sequence dataset for referencebased chimera control in environmental sequencing efforts. Microbes and Environments 30, 145-150.

Palozzi, J.E., Lindo, Z., 2018. Are leaf litter and microbes team players? Interpreting home-field advantage decomposition dynamics. Soil Biology and Biochemistry 124, 189-198.

Perez, G., Aubert, M., Decaens, T., Trap, J., Chauvat, M., 2013. Home-Field Advantage: a matter of interaction between litter biochemistry and decomposer biota. Soil Biology and Biochemistry 67, 245-254.

Purahong, W., Kahl, T., Krüger, D., Buscot, F., Hoppe, B., 2019. Home-field advantage in wood decomposition is mainly mediated by fungal community shifts at "home" versus "away". Microbial Ecology 78, 725-736.

Purahong, W., Wubet, T., Lentendu, G., Schloter, M., Pecyna, M.J., Kapturska, D., Hofrichter, M., Krüger, D., Buscot, F., 2016. Life in leaf litter: novel insights into community dynamics of bacteria and fungi during litter decomposition. Molecular Ecology 25, 4059-4074.

R Core Team, 2018. R: A Language and Environment for Statistical Computing. R Foundation for Statistical Computing, Vienna, Austria. URL. https://www.R-project. org/.

Rowland, A.P., Roberts, J.D., 1994. Lignin and cellulose fractionation in decomposition studies using acid-detergent fibre methods. Communications in Soil Science and Plant Analysis 25, 269-277.

St John, M.G., Orwin, K.H., Dickie, I.A., 2011. No 'home' versus 'away' effects of decomposition found in a grassland-forest reciprocal litter transplant study. Soil Biology and Biochemistry 43, 1482-1489.

Strickland, M.S., Osburn, E., Lauber, C., Fierer, N., Bradford, M.A., 2009. Litter quality is in the eye of the beholder: initial decomposition rates as a function of inoculum characteristics. Functional Ecology 23, 627-636.

Tedersoo, L., Bahram, M., Põlme, S., Kõljalg, U., Yorou, N.S., Wijesundera, R., Ruiz, L.V., Vasco-Palacios, A.M., Thu, P.Q., Suija, A., Smith, M.E., Sharp, C., Saluveer, E., Saitta, A., Rosas, M., Riit, T., Ratkowsky, D., Pritsch, K., Põldmaa, K., Piepenbring, M., Phosri, C., Peterson, M., Parts, K., Pärtel, K., Otsing, E., Nouhra, E., Njouonkou, A.L., Nilsson, R.H., Morgado, L.N., Mayor, J., May, T.W., Majuakim, L., Lodge, D.J., Lee, S.S., Larsson, K.-H., Kohout, P., Hosaka, K., Hiiesalu, I., Henkel, T. W., Harend, H., Guo, L.-d., Greslebin, A., Grelet, G., Geml, J., Gates, G., Dunstan, W., Dunk, C., Drenkhan, R., Dearnaley, J., De Kesel, A., Dang, T., Chen, X., Buegger, F., Brearley, F.Q., Bonito, G., Anslan, S., Abell, S., Abarenkov, K., 2014. Global diversity and geography of soil fungi. Science 346, 1256688.

Thakur, M.P., Geisen, S., 2019. Trophic regulations of the soil microbiome. Trends in Microbiology 27, 771-780.

van der Putten, W.H., Mortimer, S.R., Hedlund, K., Van Dijk, C., Brown, V.K., Lepä, J., Rodriguez-Barrueco, C., Roy, J., Diaz Len, T.A., Gormsen, D., Korthals, G.W., Lavorel, S., Regina, I.S., Smilauer, P., 2000. Plant species diversity as a driver of early succession in abandoned fields: a multi-site approach. Oecologia 124, 91-99.

van der Wal, A., Geydan, T.D., Kuyper, T.W., de Boer, W., 2013. A thready affair: linking fungal diversity and community dynamics to terrestrial decomposition processes. FEMS Microbiology Reviews 37, 477-494.

van der Wal, A., Ottosson, E., de Boer, W., 2015. Neglected role of fungal community composition in explaining variation in wood decay rates. Ecology 96, 124-133.

Veen, G.F., Freschet, G.T., Ordonez, A., Wardle, D.A., 2015. Litter quality and environmental controls of home-field advantage effects on litter decomposition. Oikos 124, 187-195. 
Veen, G.F., Snoek, B.L., Bakx-Schotman, T., Wardle, D.A., van der Putten, W.H., 2019. Relationships between fungal community composition in decomposing leaf litter and home-field advantage effects. Functional Ecology 33, 1524-1535.

Veen, G.F., van der Putten, W.H., Bezemer, T.M., 2018. Biodiversity-ecosystem functioning relationships in a long-term non-weeded field experiment. Ecology 99, 1836-1846.

Vivanco, L., Austin, A.T., 2008. Tree species identity alters forest litter decomposition through long-term plant and soil interactions in Patagonia, Argentina. Journal of Ecology 96, 727-736.

Wagg, C., Bender, S.F., Widmer, F., van der Heijden, M.G.A., 2014. Soil biodiversity and soil community composition determine ecosystem multifunctionality. Proceedings of the National Academy of Sciences of the United States of America 111, 5266-5270.

Wall, D.H., Bradford, M.A., St John, M.G., Trofymow, J.A., Behan-Pelletier, V., Bignell, D.E., Dangerfield, J.M., Parton, W.J., Rusek, J., Voigt, W., Wolters, V., Gardel, H.Z., Ayuke, F.O., Bashford, R., Beljakova, O.I., Bohlen, P.J., Brauman, A. Flemming, S., Henschel, J.R., Johnson, D.L., Jones, T.H., Kovarova, M.,
Kranabetter, J.M., Kutny, L.E.S., Lin, K.-C., Maryati, M., Masse, D., Pokarzhevskii, A., Rahman, H., SabarÁ, M.G., Salamon, J.-A., Swift, M.J., Varela, A, Vasconcelos, H.L, White, D.O.N., Zou, X., 2008. Global decomposition experiment shows soil animal impacts on decomposition are climate-dependent. Global Change Biology 14, 2661-2677.

Wang, M., Ruan, W., Kostenko, O., Carvalho, S., Hannula, S.E., Mulder, P.P.J., Bu, F., van der Putten, W.H., Bezemer, T.M., 2019. Removal of soil biota alters soil feedback effects on plant growth and defense chemistry. New Phytologist 221, 1478-1491.

Wang, Q.K., Zhong, M.C., He, T.X., 2013. Home-field advantage of litter decomposition and nitrogen release in forest ecosystems. Biology and Fertility of Soils 49, 427-434.

Wardle, D.A., Yeates, G.W., Watson, R.N., Nicholson, K.S., 1995. The detritus food-web and the diversity of soil fauna as indicators of disturbance regimes in agroecosystems. Plant and Soil 170, 35-43.

Zhang, W., Yuan, S., Hu, N., Lou, Y., Wang, S., 2015. Predicting soil fauna effect on plant litter decomposition by using boosted regression trees. Soil Biology and Biochemistry $82,81-86$. 